\title{
The Case Study of the Assessment of Ground Water Quality and Acceptance in Residential Urban Suburbs in Bindura, Zimbabwe
}

\author{
Emaculate Madungwe, Adolf Masaga and Christopher Tafara Gadzirayi \\ Department of Environmental Science, Bindura University of Science Education, Bindura 0712, Zimbabwe
}

Received: May 27, 2011 / Accepted: November 21, 2011 / Published: April 20, 2012.

\begin{abstract}
The research centered on the groundwater quality parameters in five boreholes and three wells in residential urban areas of Zimbabwe. Ten runs of chemical analysis for water $\mathrm{pH}$, EC (electrical conductivity), water hardness were carried out weekly and averages were calculated for each at Bindura University laboratory. Iron concentrations analysis was done at the Tobacco Research Station. The results from boreholes and wells were compared to the WHO (World Health Organisation) drinking water acceptable standards to measure the deviations. It was found that the boreholes had hard waters (112 mg/L), EC (425 s/m) and iron concentration (0.49 ppm) outside the WHO standards (> $64 \mathrm{mg} / \mathrm{L} ; 400 \mathrm{~s} / \mathrm{m} ; 0.3 \mathrm{ppm}$ respectively). In contrary the wells had only the water $\mathrm{pH}$ slightly outside the acceptable ranges (5.8); other parameters were in the acceptable ranges (EC $379 \mathrm{~s} / \mathrm{m}$; water hardness $0.38 \mathrm{mg} / \mathrm{L}$ as $\mathrm{CaCO}_{3}$ and iron concentration $0.38 \mathrm{ppm}$ ). The difference in chemical composition between the boreholes and wells caused the borehole water rejection in favor of well water. High iron concentrations and water hardness in boreholes were major contributors to the water rejection by the residents.
\end{abstract}

Key words: Ground water, quality, residential suburbs.

\section{Introduction}

\subsection{Domestic Water Demand}

The average urban household size in Chipadze and Chiwaridzo, Bindura urban was estimated to be six people. The current urban population size is almost doubling the 2001 population, a case which was predicted to happen not earlier than 2011. This resulted in the developments of new residential areas to accommodate the increased population.

Expansion and development in residential areas strained both water reticulation infrastructure and water quantity supplied. Presently, the water reticulation pipes and valves are always leaking. The growth and development of urban areas was further increased by the attainment of the provincial capital

Corresponding author: Emaculate Madungwe, master, main research field: water and environment. E-mail: immacforever@yahoo.co.uk. status of some towns. The move further encouraged the rural-urban migration. The youths came to seek job opportunities in the town. The rural farmers purchased or built houses in the town so that during the off-crop period they would enjoy their profits in town. The current water demand per capita is $103 \mathrm{~m}^{3}$ and $443 \mathrm{~m}^{3}$ per annum for high and low density suburbs respectively [1].

\subsection{Water Demand Management}

Municipalities did very little as far as water demand management was concerned. The municipalities relied solely on water rationing and water pricing tools for the water demand management [2]. The water supply and reticulation services have not improved as the municipalities are having severe shortages of foreign currency. Both the water supply and reticulation infrastructure repairing and replacement calls for large capital investments, that is currently an obstacle to the 
cash strapped towns of Zimbabwe [3, 4].

\subsection{Water Supply Management}

Towns are developing BTCMP (Combinational Master Plans) in order to increase the water supply by building additional dams. The current urban water shortages have been partially been alleviated by the donor program that sank boreholes mainly in high density residential areas. The borehole program got an excellent welcome by the residents at first. That was evidenced by the long queues at the boreholes and a remarkable scenic view of people carrying water containers to and from the boreholes. Then, there was a sudden change of mind by the community. The residents returned to their former unprotected water wells for daily water supplement, foregoing the newly sunk boreholes. The move stunned everyone outside, including the public health practitioners who had fought hard to eradicate the cholera problem that had claimed many people's lives in urban areas [5]. In response, the communities complained on the borehole water hardness and palatability problems. The situation had to improve, before the community was attacked by other water borne disease(s) such as typhoid and dysentery, especially in the rainy seasons. The communities' allegations call for rapid water quality analysis.

\subsection{Overall Objective}

The study sought to determine the water quality parameters in the boreholes and wells in urban residential areas in Zimbabwe and acquire consumer perceptions on the acceptability of the water.

\section{Methodology}

Water samples were collected from the boreholes and wells. The chemical parameters were analyzed at the Bindura University Laboratory. The iron concentrations were analyzed at the Tobacco Research Station laboratory using spectrophotometer. The interviews were done in randomly selected high density areas using guiding questions.

\subsection{Study Site}

The communities' boreholes are located at shopping centers for easy accessibility by the residents. Wells on the other hand are found where water can easily be accessed along water ways. The streams are found closer to the water sources and influence the water source quality (Fig. 1).

The study area lies between 31.180 longitude and 17.850 latitude at an altitude of $1,300 \mathrm{~m}$. Bindura is in agro ecological region 2, with an average annual rainfall between 700 and $1,000 \mathrm{~mm}$. Soils are primarily granite paraferrallictic with felsic metavolcanic aquifer



Fig. 1 The sketch map of two high density urban communities (not to scale). 
geology [6]. Table 1 gives the description of the boreholes and wells under the study.

\subsection{Water Sampling}

Airtight and clean 2 L samples were collected from each borehole and well using clean plastic containers. The water was pumped to the surface manually and thereafter samples were collected for laboratory analysis.

\subsection{Laboratory Analysis}

\subsubsection{Water Hardness}

The borehole water samples were titrated using 50 $\mathrm{mL} 0.01 \mathrm{M}$ EDTA in the $\mathrm{pH} 10, \mathrm{NH}_{3}-\mathrm{NH}_{4} \mathrm{Cl}$ buffer solution in the presence of $0.5 \%$ (wt/vol) Eriochrome Black T indicator. Water hardness was expressed as the equivalent number of milligrams of $\mathrm{CaCO}_{3}$. The calcium concentrations and magnesium concentrations were analyzed differently. The above procedure was used to find the total hardness of both $\mathrm{Ca}^{2+}$ and $\mathrm{Mg}^{2+}$. The $\mathrm{Ca}^{2+}$ concentrations were found by use of $1 \mathrm{M}$ $\mathrm{NaOH}$ that precipitates $\mathrm{Mg}(\mathrm{OH})_{2}$ at $\mathrm{pH}$ 12. The magnesium ion concentration was found by subtraction from the first titration value. The hydroxynaphathol blue indicator was used in the second titration.

\subsubsection{Iron Concentrations}

The iron standard samples were prepared using 1,10-phenathroline, $\mathrm{Fe} \quad\left(\mathrm{C}_{12} \mathrm{H}_{8} \mathrm{~N}_{2}\right)^{2+}{ }_{3} \quad$ and Hydroxylamine in $100 \mathrm{~g} / \mathrm{dm}^{3}$ sodium acetate solution. This was done to stabilize and maintain the iron in form of $\mathrm{Fe}^{2+}$. The iron concentrations in water were determined by the use of digital FAAS (flame atomic absorption spectrophotometer). The spectroscopy was calibrated using standards 0.1, 0.2, 0.5, 1.0, 2.5 ppm iron at $500 \mathrm{~nm}$ radiation band.

\subsubsection{Electrical Conductivity}

The electrical conductivity was measured using the digital electrical conductivity meter. The meter was first calibrated using the distilled water that has the zero electrical conductivity.

\subsubsection{PH}

The water $\mathrm{pH}$ of the borehole sample was measured by dipping digital $\mathrm{pH}$ meter leads in water. The meter was calibrated using the buffer solution at pH 10.

\subsubsection{Interviews}

The interviews were done to assess perceptions on water taste problems, soap consumption and the staining of clothes. The respondents were taken from people in the urban community using random sampling technique. Sixty people were sampled at each area surrounding the borehole. On average each borehole was expected to serve at least 200 people [7].

\section{Results}

\section{$3.1 \mathrm{pH}$}

Mupandenyama shopping centre (B1) was the only one that was slightly above the WHO's minimum drinking water $\mathrm{pH}$ acceptable range. Other boreholes and wells are generally below the standard. Renn mine well (W1) was the most acidic of all the water abstraction points. No water bodies have been found above the maximum acceptable range of $\mathrm{pH} 8$.

WHO's drinking water guideline of acceptable $\mathrm{pH}$ ranges between 6.5 and 8.5. Boreholes mean water $\mathrm{pH}$ was 6.7 and standard deviation is 0.27 . Wells mean

Table 1 Summary of the boreholes and wells [6].

\begin{tabular}{lll}
\hline Borehole/well & Depth (m) & Potential pollution sources \\
\hline Mupandenyama borehole (B1) & 30 & Sewage, acid mine drainage (Trojan Mine) \\
Bhasvi borehole (B2) & 30 & Sewage \\
Aerodrome borehole (B3) & 36 & Acid mine drainage, sewage \\
Chipadze borehole (B4) & 30 & Acid mine drainage \\
Main flea market borehole (B5) & 30 & Sewage, acid mine drainage \\
Mupandenyama well (W1) & 1.4 & Sewage \\
Main flea market well (W2) & 1.5 & Sewage \\
Chipadze well (W3) & 1.5 & Acid mine drainage \\
\hline
\end{tabular}


pH was 5.98 and standard deviation is 0.33 (Fig. 2).

\subsection{Electrical Conductivity}

The boreholes were either above or below the WHO's acceptable value of $400 \mathrm{~s} / \mathrm{m}$. Boreholes at Mupandenyama shopping centre (B1) and Main flee market (B5) were above the mark, whilst the borehole at Bhasvi shopping center (B2) and Chipadze shopping center (B4) were remarkably below the mark just as good as W1. The borehole at the Aerodrome shopping center (B3) and Mupandenyama well (W2) were just on the mark.

WHO drinking water guidelines for EC is $400 \mathrm{~s} / \mathrm{m}$. Boreholes mean water electrical conductivity was 425 $\mathrm{s} / \mathrm{m}$ and standard deviation is $63 \mathrm{~s} / \mathrm{m}$. Wells mean water electrical conductivity was $379 \mathrm{~s} / \mathrm{m}$ and standard deviation is $32.79 \mathrm{~s} / \mathrm{m}$ (Fig. 3).

\subsection{Iron Concentration}

All the sampling stations were above the WHO's drinking water guidelines acceptable value of $0.3 \mathrm{ppm}$. However, the deviations differ with great margins at sampling points. Boreholes 2 and 4 are almost doubling the acceptable value. B1, B4 and W3 were almost at half way above the normal range. W1 and W2 were slightly above acceptable value.

Thinner horizontal line is the WHO drinking water standard of $0.3 \mathrm{ppm}$. Bar graph blocks are iron concentrations at sampling stations. Boreholes mean water iron concentration is $0.49 \mathrm{ppm}$ and standard deviation is $0.06 \mathrm{ppm}$. Wells mean water iron concentration is $0.38 \mathrm{ppm}$ and standard deviation is 0.06 ppm (Fig. 4).

\subsection{Water Hardness}

Generally, the boreholes had hard waters whilst the wells had soft water. Boreholes 3, 4 and 5 were almost doubling the boundary value of $64 \mathrm{mg} / \mathrm{L}$ that is the threshold value for hard water. The water hardness is expressed as $\mathrm{CaCO}_{3}$ equivalent in mg per liter. Bar

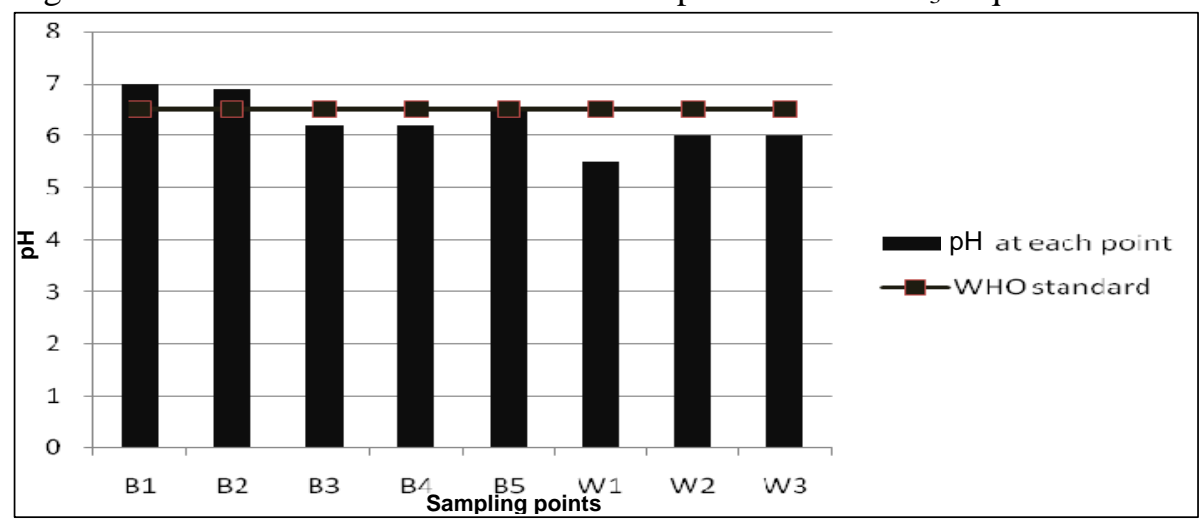

Fig. 2 The water $\mathrm{pH}$ at different sampling points.

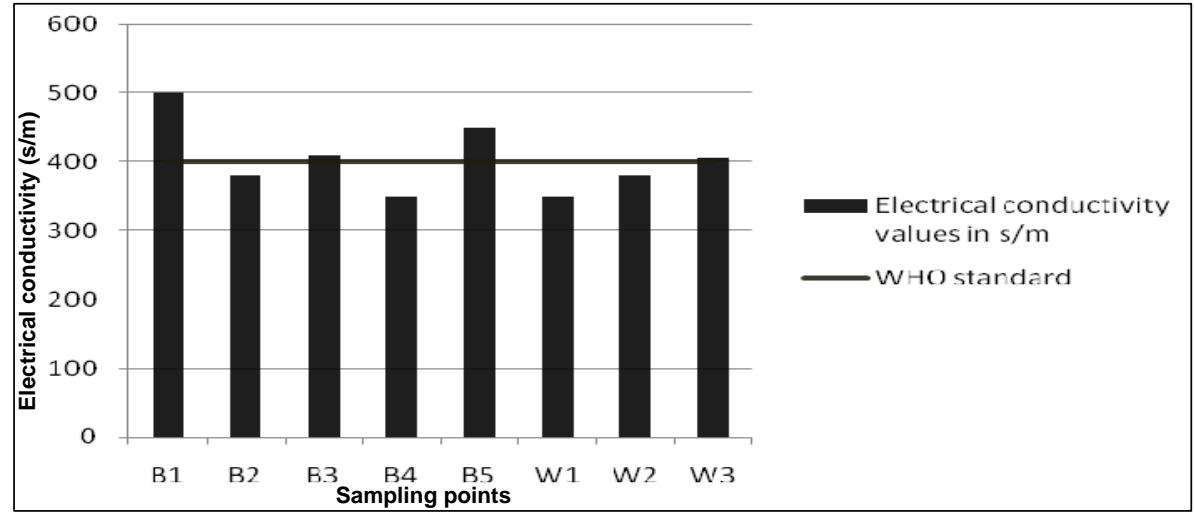

Fig. 3 The electrical conductivity at sampling points. 


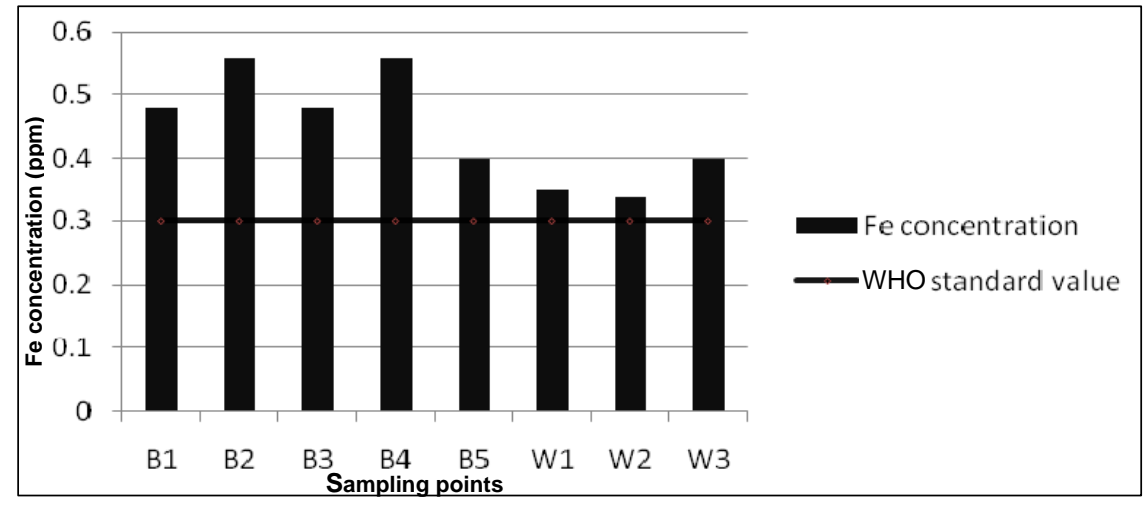

Fig. 4 The iron concentrations at sampling points.

graphs in Fig. 5 are water hardness at various sampling points whilst continuous horizontal line represents WHO guidelines for drinking water. The wells mean water hardness was $50 \mathrm{mg} / \mathrm{L}$ and the standard deviation is $0.05 \mathrm{mg} / \mathrm{L}$. The borehole water mean water hardness was $112.8 \mathrm{mg} / \mathrm{L}$. The standard deviation was $23 \mathrm{mg} / \mathrm{L}$.

\subsection{Community Response to Water Problems}

Soap consumption and poor taste were the most common problems cited by the residents as compared to the clothes staining problem. In all the water problems, there was none that had more than half of the respondents complaining of the problem. The highest proportion was $50 \%$ in B1 and B4 soap consumption problems. Table 2 shows the proportion of the respondents that complained of the specific water problem at each borehole.

\section{Discussion}

\subsection{Water $p H$}

The boreholes (B3 and B4) closer to the Renn Mine dumps had the acidic water that was outside the WHO's drinking water standard region of 6.5-8.5. The acidic water $\mathrm{pH}$ of the Renn Mine well shows that the mine acidifies the surface as well as subsurface water sources [8]. Ironically, the wells were outside the WHO standards whilst the boreholes were within the WHO standards. The differences in water $\mathrm{pH}$ were minor while other parameters like iron and water hardness had bigger impacts that greatly influenced the public decisions [9].

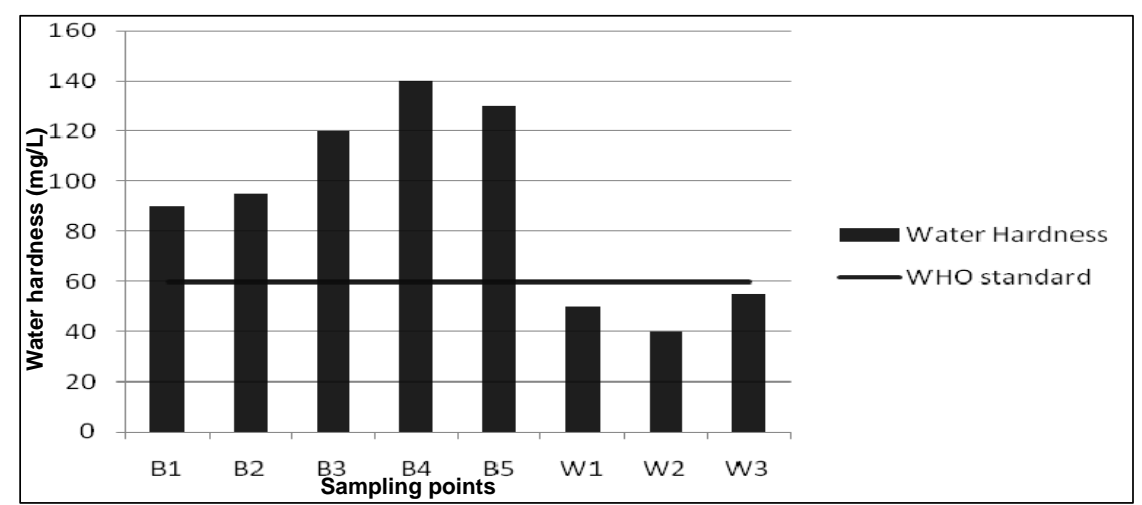

Fig. 5 Water hardness at sampling points.

Table 2 Public perceptions to the borehole water problems expressed in percentages of the total respondents (\%).

\begin{tabular}{lllllll}
\hline Proportion of water problem complains & B1 & B2 & B3 & B4 & B5 & Average (\%) \\
\hline Soap consumption & 50 & 40 & 30 & 50 & 30 & 40 \\
Clothes staining & 10 & 10 & 20 & 25 & 30 & 19 \\
Poor taste & 40 & 40 & 30 & 25 & 40 & 35 \\
\hline
\end{tabular}




\subsection{Electrical Conductivity and Water Hardness}

The Mupandenyama (B1) and Main Flea Market (B5) boreholes had the electrical conductivity (EC) that was well above the WHO standards. Obviously that could have caused the water rejection by the public. High EC could mean high presence of saline ions like sodium and chlorides. The same could be said to the presence of other divalent ions like manganese that cause water hardness as well as clothes staining. In a nutshell, it is a reflection of the total water ionic content. The above named borehole water must first be passed through an ion exchange resin to remove the problem ions to make the water acceptable by the residents. The two boreholes are close to the streams that have tributaries from the town area and Renn Mine. It follows that the situation mimics the riverbank filtration scenario, where the contaminated water is filtered by the river bank (artificially made) before use [10, 11]. However unlike the proper riverbank filtration, the stream bank here is not built by clay surfaces. Hence the pollutants from either source are likely to enter the borehole water. For the reasons outlined above, the B1 has the highest electrical conductivity. High EC is an indication of presence of ionic chemical species. Storm drain from town would discharge lead ions from the vehicle exhaust fumes. The abandoned mine tailings are likely to be continuously mineralizing and discharging pollutants that would find their way into the borehole $[12,13]$. All the boreholes had hard water whilst the wells had soft water. Clearly it showed that water hardness in the boreholes was another source of problem. The residents could have opted for softer water from wells.

\subsection{Iron Concentrations}

All the water bodies showed the iron content outside WHO's acceptable region, that is above $0.3 \mathrm{ppm}[9,12]$. However, the wells were slightly above the acceptable standard. Wells were ranging from 0.36 to $0.4 \mathrm{ppm}$, whilst the boreholes were from 0.4 to $0.59 \mathrm{ppm}$.
Therefore, high iron problem was one of the causes of borehole water rejection by the public in all the boreholes. The borehole steel parts may add the excess iron due to corrosion [10]. In the future the steel parts should be very rigid such that they do not easily wear out. Iron could also be coming from aquifer bedrock that weather into confined aquifers, the source for borehole water [3, 5]. Again the water should be passed through the ion exchange resin to remove the iron ions.

\subsection{Public Perceptions}

\subsubsection{High Soap Consumption}

The problem of high soap consumption was cited by respondents in all the boreholes. The highest numbers of complaints were for B1 and B4 that had $50 \%$ followed by B2 with $40 \%$ and B3 and B5 had $30 \%$ each. High soap consumption was caused by high EC and calcium as well as magnesium. It follows that B1 and B5 had the highest EC and also had highest complaints of high soap consumption. Iron (II) being divalent ions contributes to water hardness [14]. The public responses are very subjective. They depended on water use by the residents. Some may not use the water for drinking, so did not realise water taste problems.

\subsubsection{Clothes Staining Problems}

Cases of clothes staining had relatively less complaints. This may be caused by the high water hardness that impedes water usage. As a result very few respondents would be able to realise staining problems. Only those who had opportunity to use it for laundry would realise the problem. Similarly, it depended on the type of clothes that constitute the respondents' wardrobe. White and bright colours are easy to identify the stains as compared to dark ones.

\subsubsection{Astringent Water Taste}

Poor taste problems were caused by a number of attributes such as water $\mathrm{pH}$, high iron content and high water hardness. The complaints were comparable to those of high soap consumption. This was due to inter dependence of parameters that caused both complaints. 
For instance, water $\mathrm{pH}$ affects the solubility of ions that cause water hardness $[3,11]$. It must not be ignored that the respondents are not trained personnel who knew correctly water taste. Water taste affects the water users directly unlike clothes staining and high soap consumption. Consequently, respondents were more sensitive on the issue than any other. Those who had no complaints may not be using the water for drinking purposes. Alternatively, they may be boiling the water before use. Boiling the water removes the temporary water hardness leaving permanent water hardness. As a result the impact of water hardness would have been reduced. The results are similar to those found in other parts of Africa, regardless of geographical differences and cultures $[3,5,15]$.

\section{Conclusions and Recommendations}

High water hardness and iron content in all the boreholes proved to the major causes of borehole water rejection in favor of well water. Other chemical parameters like electrical conductivity and low water $\mathrm{pH}$ were the main reasons in Aerodrome and Main Flea market boreholes. The two boreholes suffered from acid mine drainage from an abandoned Mine nearby. The effluent sewage water from the stabilization ponds caused mild water problems to Mupandenyama borehole. The overcrowding of the boreholes in the area around the Bhasvi shopping caused local groundwater mining.

From the study, the following recommendations were made:

- The water should at least be boiled before use to reduce water hardness;

- Residents should use resin to further purify water;

- Residents should fetch water early to avoid peak-water periods;

- Residents should use large water containers to avoid water fetching errands;

- Residents who opted for the water for the wells should use chlorine tablets for disinfection purposes;
- Water planners and managers should involve residents at initial borehole planning stage.

\section{References}

[1] The Bindura Municipality Annual Report, Welstam Publishers, Harare, 2009, pp. 12-37.

[2] C.A.T. Katsvanga, E.D. Bobo, D. Gwenzi, L. Jimu, A. Kudhlande, T. Nyamugure, Vegetation diversity and composition of bindura mining town in Zimbabwe, African Journal 44 (2000) 267-269.

[3] UNICEF, Mashonaland Central Province Borehole Program, UNICEF, Harare, 2009, p. 56.

[4] A. Rahman, Groundwater as a source of contamination in rapid growing megacities in Asia: Case of Karachi, Pakistan, Water and Science Technology 34 (1999) 7-9

[5] B.L. Morris, A.R. Lawrence, P.J. Chilton, B. Adams, R. Carlow, A. Klinckb, Groundwater and Its Susceptible to Degradation: A Global Assessment of Problems and Options for Management, United Nations Environment Programme [Online], Nairobi, Kenya, http//www.unep.org/DEWA/water/.

[6] Global Water Partnership, A Handbook for Integrated Water Resources Management, 2009, pp. 567-571.

[7] F. Steenbergen, A. Tuinhof, Managing the Buffer for Development and Climate Change Adaptation, Groundwater Recharge, Retention, Reuse and Rainwater Storage, BGR Publications, 2010, p. 23.

[8] G. Howard, Water Quality Surveillance [Online], WEDC, Loughborough University, http//wedc.lboro.ac.uk/.

[9] L. Davis, B. MacDonald, Developing and Managing Community Water Supplies, Oxfam Guidelines Number 8, London, UK, 1999, pp. 112-123.

[10] C.W. Fetter, Applied Hydrogeology, 4th ed., Prentice Hall, Englewood Cliffs New Jersey, 2001, p. 123.

[11] R.A. Bailey, S. Clark, H. Ferris, S. Krause, R.L. Strong, Chemistry of the Environment, 2nd ed., Academic Press, New York, USA, 2002, p. 317.

[12] N.S. Robbins, J. Davis, J.L. Farr, R.C. Calow, The changing role of hydrologygeology in semi-arid southern and eastern Africa, Hydrogeology Journal 14 (2008) 1467.

[13] A. Aderinwale, O.A. Ajay, The link between poverty and water supply: The Nigerian example, in poverty and water explanations of reciprocal relationships, in: D. Hemson, K. Kulindwa, H. Lein, A. Mascarenhas (Eds.), Zed Books, USA, 2008, p. 231.

[14] S.M.A. Adelana, A.M. Macdonald, Applied Groundwater Studies in Africa, IAH Selected Papers on Hydrology, CRC Press/Balkema, Leiden, The Netherlands, Vol. 13, 2008, pp. 13-17.

[15] The WHO Drinking Water Guidelines Quality, WHO, Geneva Switzerland, Vol. 1, 1993, pp. 168-243. 